\title{
Cobas MPX Test
}

National Cancer Institute

\section{Source}

National Cancer Institute. cobas MPX Test. NCI Thesaurus. Code C162530.

A proprietary qualitative polymerase chain reaction-based test used to directly detect

RNAs from human immunodeficiency virus (HIV) type 1 groups M and O, HIV-2, hepatitis

C virus (HCV) and hepatitis B Virus (HBV) in patient-derived blood samples. 